\title{
Effects of Amino Acid Nutrition on the Responses of Dairy Cows to Milking More Frequently With or Without Injection of Growth Hormone
}

\author{
J.-M. Yeo, ${ }^{*}$ C. H. Knight, ${ }^{*}$ I. M. Nevison, $†$ and D. G. Chamberlain* \\ *Hannah Research Institute, Ayr, KA6 5HL, UK \\ †Biomathematics and Statistics Scotland, \\ Hannah Research Institute, Ayr, KA6 5HL, UK
}

\begin{abstract}
The influence of amino acid nutrition on the response to milking more frequently, with or without injection of growth hormone, was examined in eight dairy cows in two $4 \times 4$ Latin squares with 28 -d periods. The four treatments were a diet adequate in amino acids with or without injection of growth hormone and a diet inadequate in amino acids with or without injection of growth hormone. For all four treatments, during the last $14 \mathrm{~d}$ of each period, one half of the mammary gland was milked three times a day $(3 \times)$, while the other half remained on twice-daily milking $(2 \times)$. Both diets were based on grass silage given ad libitum and $4 \mathrm{~kg} / \mathrm{d}$ of sugar beet pulp together with a supplement containing either fish meal (adequate diet) or feather meal (inadequate diet) as the only protein feeds. The diet containing feather meal is known to be deficient in His, Met, and Lys. On the fish meal diet, the cows responded positively to growth hormone and to milking more frequently and the responses to both treatments were additive. On the feather meal diet, however, even though injection of growth hormone increased the yield of milk protein by around $10 \%$, milking more frequently did not affect milk production. It is concluded that milking more frequently has a weaker effect on the partitioning of amino acid use between body and udder than does growth hormone treatment.
\end{abstract}

(Key words: dairy cow, amino acid partition, thricedaily milking, growth hormone)

Abbreviation key: $2 \times=$ twice-daily milking, $3 \times=$ three times daily milking, 3-MH = 3-methylhistidine, $\mathbf{M B F}=$ mammary blood flow, $\mathbf{M E}=$ metabolizable en ergy, UDP = rumen-undegradable protein .

Received December 5, 2002.

Accepted January 27, 2003.

Corresponding author: D. G. Chamberlain; e-mail: chamberlaind @hri.sari.ac.uk.

\section{INTRODUCTION}

Dairy cows produce more milk when they are milked three times daily $(\mathbf{3} \times)$ rather than twice daily $(\mathbf{2} \times)$ (Erdman and Varner, 1995). They also produce more milk when injected with growth hormone (Bauman, 1992). Moreover, when both treatments are applied together, the two effects are additive (Knight et al., 1992; Speicher et al., 1994). Different mechanisms underlie the two effects: The stimulus of more frequent milking is local to the mammary gland itself (Wilde et al., 1987), whereas the action of growth hormone derives from diverse effects in a number of tissues, leading to an altered partition of nutrients in favor of the udder (Bauman and Vernon, 1993). It is not clear, however, to what extent these mechanisms might overlap because there is some evidence that the local stimulus of more frequent milking can, in turn, cause more nutrients to be delivered to the udder at the expense of other tissues (DePeters et al., 1985; Kazmer et al., 1986), although there is no evidence of major repartitioning comparable to that seen with growth hormone injections. Repartitioning itself can be divided into two phases. When nutrient intake exceeds the requirement for milk secretion, extra nutrients can be made available to the udder solely from a repartitioning of the nutrients supplied by the daily intake. When the diet barely meets the requirement for milk secretion, the extra demands of the udder can be met only from net mobilization of body tissue. Mobilization of body tissue might require a stronger stimulus than that needed to alter the partitioning of daily nutrient intake. This line of reasoning raises the question of whether the local stimulus of more frequent milking might be strong enough to alter the partitioning of nutrient intake but too weak to provoke net mobilization of body tissue, which would contrast with the potent repartitioning effects of exogenous growth hormone. Theoretically then, it would be expected that responses to milking more frequently and to injection of growth hormone, and response to the combined treatment, would be influenced by the nutritional sta- 
tus of the cow; the present experiment was designed to test this hypothesis. Attention was focused specifically on amino acid nutrition and on the readiness of the cow to mobilize body protein.

Responses to milking three times daily rather than twice daily, with or without intramuscular injection of growth hormone, were measured in dairy cows consuming a diet that was either adequate in amino acids or deficient in the three most-limiting amino acids. Both diets were based on grass silage and cereal and were formulated to provide similar amounts of metabolizable energy (ME) and RUP, both given in excess of the requirement for milk production at the start of the experiment. The deficient diet contained feather meal as the only protein supplement; milk secretion on this diet is known to be limited by the supplies of His, Met, and Lys (Kim et al., 1999, 2000, 2001). For the nutritionally adequate diet, the supplies of these three amino acids were supplemented by replacing feather meal with fish meal.

\section{MATERIALS AND METHODS}

\section{Cows and Their Management}

The Home Office Inspectorate (United Kingdom) and the Ethical Review Committee of the Hannah Research Institute approved all animal handling and experimental procedures. Eight Friesian cows in their second lactation were used. They were 9 to $10 \mathrm{wk}$ into their lactation at the start of the experiment and weighed, on average, $568 \mathrm{~kg}(\mathrm{SD}=37.0)$. The animals were housed in a metabolism cubicle with water freely accessible. Silage and sugar beet pulp were provided using an automatic feeder (RIC HF 2 PL, Insentec B. V., Marknesse, The Netherlands) and supplements were provided in two equal meals each day at milking times. The cows were milked twice daily at 0700 and $1500 \mathrm{~h}$ with an additional milking at $2200 \mathrm{~h}$ for a $3 \times$ daily milking treatment.

Cows were given a basal diet consisting of ad libitum access to grass silage and $4 \mathrm{~kg} / \mathrm{d}$ of sugar beet pulp. Silage was made from perennial ryegrass (Lolium perenne) cut at an early stage of growth and ensiled with the addition of an inoculum of Lactobacillus plantarum (Ecosyl; ICL pcl, Billingham, UK) at $3 \mathrm{~L} /$ tonne $\left(10^{6} \mathrm{cfu} / \mathrm{g}\right.$ silage $)$ in a bunker silo of 70 -tonne capacity. The silage DM was $28.1 \%$ with $\mathrm{pH} 3.9$ and the concentrations (\% of DM) of other constituents were as follows: total nitrogen 2.18 , of which $9.7 \%$ was present as ammonia; lactic acid 8.3; water soluble carbohydrate 3.2; digestible $\mathrm{OM}$ in the $\mathrm{DM}$ 64.8. The chemical compositions of the supplements are shown in Table 1.
Table 1. The chemical composition (\% of DM, unless stated otherwise) of the feather meal cube (FMC), fish meal cube (FC) and sugar beet pulp (SBP).

\begin{tabular}{lccc}
\hline & FMC & FC & SBP \\
\hline DM, \% & 88.1 & 87.7 & 90.7 \\
OM & 91.0 & 88.8 & 88.1 \\
Total N & 4.51 & 4.75 & 1.70 \\
Starch & 26.6 & 26.4 & 0.1 \\
Sugars & 10.8 & 4.3 & 26.4 \\
\hline
\end{tabular}

\section{Experimental Treatments and Design}

The experiment was designed as a replicated $4 \times 4$ Williams Latin squares applied to groups of cows. Cows were blocked, on the basis of milk yield, into two groups at the start of the experiment. Each block contained four animals for each of which four treatments were applied in four 28 -d periods. The experimental treatments were 1) the basal diet as described above plus $5 \mathrm{~kg} / \mathrm{d}$ of a supplement containing feather meal (feather meal cube, a pelleted mixture of $50 \%$ rolled barley, $25 \%$ feather meal and $25 \%$ citrus pulp on an as-fed basis) (FE); 2) FE with administration of recombinant bovine growth hormone (bST, $30 \mathrm{mg} / \mathrm{d}$, a daily intramuscular injection, Monsanto, St. Louis, MO) (FE + bST); 3) the basal diet as described above plus $5 \mathrm{~kg} / \mathrm{d}$ of a supplement containing fish meal (fish meal cube, a pelleted mixture of $50 \%$ rolled barley, $30 \%$ fish meal, and $20 \%$ citrus pulp on an as-fed basis) (FI); 4) FI with administration of bST as described above $(\mathrm{FI}+\mathrm{bST})$. For the first $14 \mathrm{~d}$ of each period, all quarters of the cows were milked twice daily. For the rest of the period, one half-udder (left hand side) was milked $3 \times$ daily and the other half (right hand side) remained on $2 \times$ daily milking.

Food intake and milk yield from each half-udder were recorded daily. The composition of milk was determined on a representative, composite sample from the last four consecutive milkings in the second week and in the last week of each experimental period. Samples of blood were taken from a tail vessel into heparinized Vacutainer tubes at $1100 \mathrm{~h}$ on the last day of each period and centrifuged immediately to separate plasma that was stored at $-20^{\circ} \mathrm{C}$ before analysis. Spot urine collections were made at $1200 \mathrm{~h}$ by inserting a bladder catheter on the last day of each period for determination of the ratio of 3-methylhistidine (3MH)/creatinine. Mammary blood flow (MBF) from each half udder was determined at $1000 \mathrm{~h}$ on the penultimate day and on the last day of each period, for cows in groups (block) 1 and 2, respectively, by the method of Christensen et al. (1989) using Doppler ultrasound equipment (Ausonics Impact, Ausonics International Inc., CA). 


\section{Chemical Analysis}

Feeds were analyzed as described previously (Kim et al., 1999) and digestible OM in the DM in silage was determined by the method of Morrison (1972). Milk samples were analyzed for fat, protein, and lactose concentrations with an infrared milk analyser (Milcoscan, Foss Electric, Hillerød, Denmark). Glucose in plasma was determined spectrophotometrically with a commercial kit (Boehringer Mannheim GmbH, Germany) and plasma NEFA was measured by the method of Itaya and Ui (1965). Growth hormone in plasma was analyzed using a double-antibody radioimmunoassay (Vernon et al., 1981). IGF-I in plasma was extracted and analyzed using a radioimmunoassay as described by Flint and Gardner (1989). The concentration of creatinine in urine was determined by the method of Shingfield and Offer (1999) using HPLC under isocratic conditions and that of 3MH by the method of Wassner et al. (1980) using HPLC with fluorescamine precolumn derivatization.

\section{Statistical Analysis}

For statistical analysis, mean values for feed intake and milk yield from each half-udder were taken for the last $7 \mathrm{~d}$ of each experimental period. An additional mean value for milk yield from each half-udder was taken for the last $7 \mathrm{~d}$ of the second week in each period. Results from the last week of each experimental period were analyzed by ANOVA using the directives of Genstat 5 (Lawes Agricultural Trust) for two Williams Latin squares with a factorial treatment structure for diet and bST combinations with milking frequency as a subplot treatment applied to udder halves. Treatment differences in milk production between $2 \times$ and $3 \times$ milking were compared by analysis of covariance with the response from the second week in each period as a covariate.

One of the cows had a high body temperature during the third period, and her silage intake and milk production were depressed. She recovered well during the rest of the experiment, but the data for this cow for period 3 were excluded from the statistical analysis.

\section{RESULTS}

Results for milk production and MBF from the whole udder, and feed intake and BW are given in Table 2. There were no significant interactions between the diet and the bST treatment either in feed intake or in milk production. As regards the main effects of the diet and the bST treatments, DMI was not affected by the bST treatment. The feather meal diet, however, significantly reduced silage and total DMI. Yields of milk and milk constituents were significantly higher for the fish meal diet than for the feather meal diet. Compared with the feather meal diet, the fish meal diet significantly increased the concentration of milk protein but decreased that of milk fat. The bST treatment significantly increased the yield of milk and milk constituents, and the concentration of milk fat and lactose but decreased milk protein concentration. The feather meal diet $(P=0.064)$ and the bST treatment $(P=0.052)$ tended to increase MBF. Body weight was higher for the fish meal diet than for the feather meal diet.

Results for the effects of $3 \times$ milking on milk production and MBF are given in Table 3. As regards the main effects of frequent milking, the $3 \times$ milking significantly increased the yield of milk and milk constituents, lactose concentration, and MBF. However, there were significant interactions between milking frequency and the diet treatments in the yield of milk, milk protein, and lactose. When comparisons between the $2 \times$ and the $3 \times$ milkings were made within each treatment, the $3 \times$ milking significantly $(P<0.05)$ increased the yield of milk, milk protein, and lactose for the FI and the FI + bST treatments but did not affect it for the FE and the FE + bST treatments. There was a very small, but significant, increase in the concentration of milk lactose by the $3 \times$ milking on the $\mathrm{FE}$ and the FI + bST treatments.

For the main effects, the bST treatment tended ( $P$ $=0.057)$ to increase the concentration of NEFA and significantly increased that of growth hormone and IGF-I (Table 4). The ratio of 3-MH/creatinine in urine was significantly lower for the feather meal diet than for the fish meal diet. Although there was a significant interaction in the ratio of $3-\mathrm{MH} /$ creatinine, the bST treatment did not significantly affect it when comparisons were made within each dietary treatment.

\section{DISCUSSION}

Before beginning a detailed discussion of the results, some limitations of the experimental design should be noted. The substantial difference in milk yield between the fish meal and the feather meal diets agrees well with that seen before (Chamberlain et al., 1992), but the numerically similar responses to injection of bST on the two treatments must be interpreted carefully. It is difficult to see how the effects of growth hormone injection on the feather meal treatment could be sustained in the longer term. If the response to growth hormone on the feather meal treatment depends on mobilization of body protein, then the combination of short period lengths and a changeover design, leading to alternating depletion and replenishing 
YEO ET AL.

Table 2. Milk production and mammary blood flow (MBF) from whole udder, and body weight of cows.

\begin{tabular}{|c|c|c|c|c|c|c|c|c|}
\hline & \multicolumn{4}{|c|}{ Treatment ${ }^{1}$} & \multirow[b]{2}{*}{$\mathrm{SED}^{2}$} & \multicolumn{3}{|c|}{ Effect } \\
\hline & $\mathrm{FE}$ & $\mathrm{FE}+\mathrm{bST}$ & FI & $\mathrm{FI}+\mathrm{bST}$ & & Diet & bST & $\begin{array}{l}\text { Diet } \\
\times \text { bST }\end{array}$ \\
\hline \multicolumn{9}{|l|}{$\mathrm{DMI}, \mathrm{kg} / \mathrm{d}$} \\
\hline Silage & 10.9 & 10.7 & 11.6 & 11.5 & 0.35 & $* *$ & $\mathrm{NS}^{3}$ & NS \\
\hline Total & 18.0 & 18.1 & 19.9 & 20.1 & 0.34 & $* * *$ & NS & NS \\
\hline Milk yield, kg/d & 19.0 & 22.0 & 24.4 & 27.3 & 0.81 & $* * *$ & $* * *$ & NS \\
\hline Protein, g/kg & 32.4 & 30.7 & 33.1 & 31.7 & 0.42 & $*$ & $* * *$ & NS \\
\hline Protein, g/d & 616 & 675 & 803 & 865 & 23.2 & $* * *$ & $* *$ & NS \\
\hline Fat, $\mathrm{g} / \mathrm{kg}$ & 42.7 & 47.1 & 39.2 & 41.6 & 1.75 & $* *$ & $*$ & NS \\
\hline Fat, g/d & 806 & 1034 & 950 & 1137 & 52.0 & $* *$ & $* * *$ & NS \\
\hline Lactose, $\mathrm{g} / \mathrm{kg}$ & 47.7 & 48.6 & 47.3 & 48.2 & 0.37 & NS & $* *$ & NS \\
\hline Lactose, $\mathrm{g} / \mathrm{d}$ & 907 & 1070 & 1155 & 1317 & 41.3 & $* * *$ & $* * *$ & NS \\
\hline $\mathrm{MBF}, \mathrm{L} / \mathrm{min}$ & 15.1 & 16.8 & 13.8 & 15.2 & 1.05 & NS & ?S & NS \\
\hline Body weight, kg & 589 & 591 & 600 & 601 & 4.9 & $* * *$ & NS & NS \\
\hline
\end{tabular}

${ }^{1}$ See text for details of treatments.

${ }^{2} \mathrm{SED}$, standard error of differences.

${ }^{3} \mathrm{NS}$, Not significant.

$* P<0.05$.

$* * P<0.01$

$* * * P<0.001$.

of body protein stores, could give a very misleading impression of responses to be expected under practical conditions. Again, responses to bST in short-term trials will be determined by nutritional status and whether feed intake is increased. As well as influencing the magnitude of the response of milk yield, such factors will affect the changes in milk composition, particularly milk protein concentration. As would be expected, if bST induces repartition of nutrients towards the mammary gland at the expense of other body tissues, and feed intake is not increased, the fall in energy status of the cow will be reflected in a fall in the concentration of milk protein (Coulon and Rémond, 1991) as seen in the present experiment for both the feather meal and fish meal treatments. It should also be noted that the increased frequency of milking was applied to only one half of the mammary gland; the stimulus would be expected to be greater if the treatment had been applied to the whole udder. Because it can be argued that associated changes in feed intake are part and parcel of the animal's response to a change in amino acid nutrition, we decided

Table 3. Milk production (means adjusted for the response in the second week of each period as a covariate) and mammary blood flow (MBF) from each half-udder.

\begin{tabular}{|c|c|c|c|c|c|c|c|c|c|c|c|c|c|}
\hline & \multicolumn{8}{|c|}{ Treatments $^{1}$} & \multirow[b]{3}{*}{$\mathrm{SED}^{2}$} & \multicolumn{4}{|c|}{ Effect } \\
\hline & \multicolumn{2}{|c|}{$\mathrm{FE}$} & \multicolumn{2}{|c|}{$\mathrm{FE}+\mathrm{bST}$} & \multicolumn{2}{|c|}{ FI } & \multicolumn{2}{|c|}{$\mathrm{FI}+\mathrm{bST}$} & & \multirow[b]{2}{*}{$\mathrm{MF}^{3}$} & \multirow{2}{*}{$\begin{array}{l}\mathrm{MF} \\
\times \text { Diet }\end{array}$} & \multirow{2}{*}{$\begin{array}{l}\mathrm{MF} \\
\times \mathrm{bST}\end{array}$} & \multirow{2}{*}{$\begin{array}{l}\text { MF } \\
\times \text { Diet } \\
\times \text { bST }\end{array}$} \\
\hline & $2 \times$ & $3 \times$ & $2 \times$ & $3 \times$ & $2 \times$ & $3 x$ & $2 \times$ & $3 \times$ & & & & & \\
\hline Milk yield, $\mathrm{kg} / \mathrm{d}$ & 9.7 & 10.0 & 10.9 & 11.4 & 11.5 & 12.8 & 12.7 & 13.7 & 0.36 & $* * *$ & * & NS & NS \\
\hline Protein, g/kg & 32.5 & 32.2 & 31.5 & 31.5 & 32.1 & 32.2 & 31.9 & 32.0 & 0.16 & $\mathrm{NS}^{4}$ & NS & NS & NS \\
\hline Protein, g/d & 310 & 317 & 332 & 351 & 376 & 422 & 408 & 444 & 12.7 & $* * *$ & * & NS & NS \\
\hline Fat, $\mathrm{g} / \mathrm{kg}$ & 42.9 & 42.0 & 46.3 & 46.4 & 39.5 & 41.0 & 42.2 & 41.2 & 1.25 & NS & NS & NS & NS \\
\hline Lactose, g/d & 465 & 483 & 529 & 551 & 547 & 612 & 605 & 659 & 17.6 & $* * *$ & * & NS & NS \\
\hline $\mathrm{MBF}, \mathrm{L} / \mathrm{min}$ & 7.0 & 8.1 & 7.8 & 9.1 & 6.3 & 7.5 & 7.0 & 8.2 & 0.79 & ** & NS & NS & NS \\
\hline
\end{tabular}

${ }^{1}$ See text for details of treatments.

${ }^{2} \mathrm{SED}$, standard error of differences. For comparisons of the effects of frequent milking within each treatment use LSD $=2.056(t$ value $)$ $\times \operatorname{SED}(P<0.05)$.

${ }^{3} \mathrm{MF}$, Milking frequency.

${ }^{4} \mathrm{NS}$, Not significant.

$* P<0.05$.

$* * P<0.01$.

$* * * P<0.001$. 
Table 4. The composition of plasma and the ratio $(\mu \mathrm{mol} / \mathrm{mmol})$ of 3 -methylhistidine $(3-\mathrm{MH}) / \mathrm{creatinine}$ in urine.

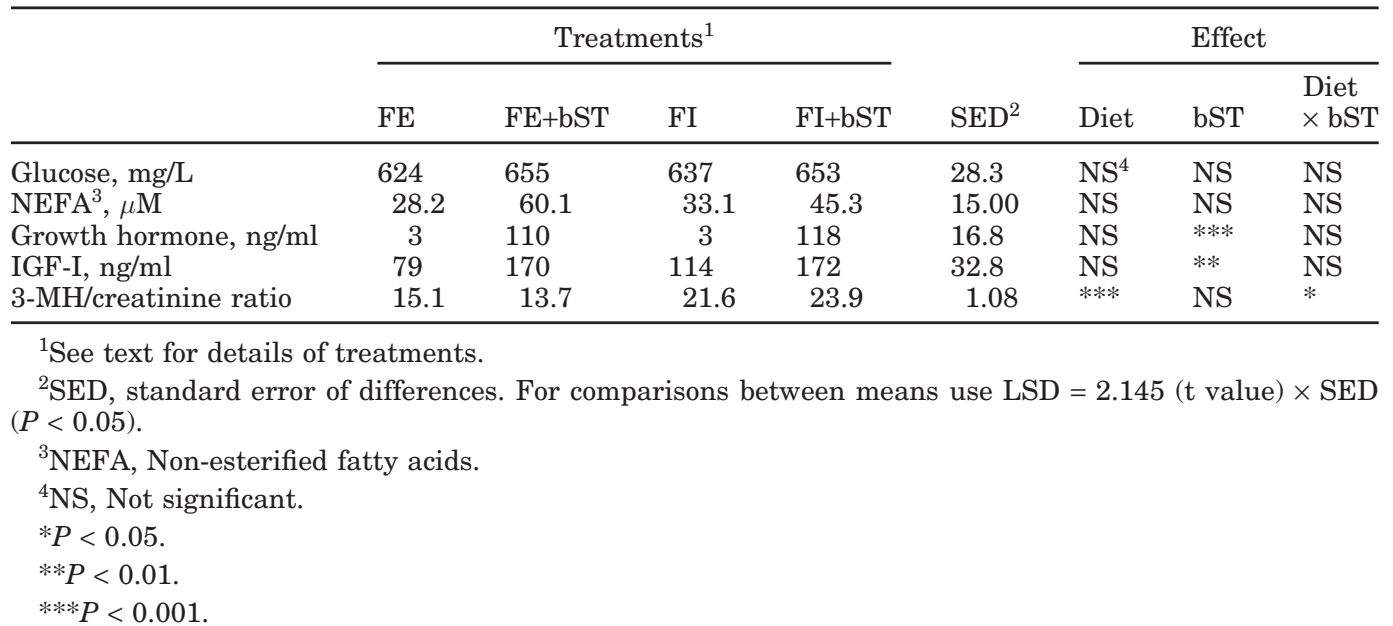

to allow the cows ad libitum access to silage in the present experiment. The drawback, however, is that differences in silage intake between the treatments can cloud the interpretation of the results because it might be argued that the responses of milk production were due to differences in energy intake rather than amino acid supply. Nevertheless, although the feather meal diet decreased silage intake relative to the fish meal diet, it was estimated that the cows consumed $\mathrm{ME}$ in excess of their requirements for maintenance and milk production by approximately $45 \mathrm{MJ} / \mathrm{d}$ on both treatments (ARC, 1980). Injection of bST increased milk energy output by 13 and $11 \mathrm{MJ} / \mathrm{d}$ for the feather meal and the fish meal diets, respectively. These increases occurred without any significant changes either in feed intake or in the concentration of NEFA, which is consistent with a substantial excess of ME intake. This degree of oversupply of ME implies that milk production would be relatively insensitive to an increase in the intake of ME. This, in turn, would suggest that the large difference in milk production between the treatments is not due to the difference in $\mathrm{ME}$ intake of $22 \mathrm{MJ} / \mathrm{d}$. It is also worth mentioning that this interpretation is supported by the results of previous experiments with the feather meal diet, in which intravenously infused amino acids induced large increases in milk production with little or no effect on ME intake (Choung and Chamberlain, 1995; Kim et al., 1999, 2001).

Increasing the frequency of milking in cows eating the feather meal diet did not increase the yield of milk or milk protein, suggesting that the deficient dietary supplies of His, Met, and Lys blocked any increase in their secretion. Despite the lack of effect of $3 \times$ milking on the secretion of milk protein with the feather meal diet, however, the yield of milk protein with this diet was markedly increased by around $10 \%$ when the cows were injected with growth hormone, suggesting that compared with growth hormone injection, increasing the frequency of milking has, at best, only a weak effect on the partitioning of amino acid use between body and udder. The response to bST means that the amino acids necessary to fuel an increase in secretion of milk protein were potentially available in cows eating the feather meal diet. Under the action of growth hormone, a potent repartitioning agent, extra amino acids were made available to the mammary gland or, more precisely, extra amino acids were synthesized into milk protein. Moreover, the lack of effect on the ratio of 3-MH to creatinine would suggest that amino acids were diverted to the mammary gland without effects on the degradation rate of muscle protein. It should be noted, however, that an increase of urinary 3-MH output would not necessarily indicate an increased net mobilization of protein because net mobilization is the difference between the rates of muscle protein synthesis and degradation (Funabiki et al., 1976), both of which can vary independently. In addition, mobilization of body proteins other than muscle, e.g., skin or bone, could play an important part in the response (Champredon et al., 1990; Baracos et al., 1991). With the level of experimentation in this experiment, it is not possible to identify precise changes in metabolism of amino acids induced by injection of growth hormone. That would require the use of sophisticated labeling techniques for the various pools of amino acids and proteins in the body. In the absence of such quantitative information, the present experiments can be interpreted only speculatively. 
No matter what the precise mechanisms may be, it is clear that any repartitioning achieved by injection of growth hormone on the feather meal treatment could not be achieved by increasing milking frequency alone. The $3 \times$ daily milking could not influence amino acid partitioning to any measurable extent. However, experiments reported in the literature (DePeters et al., 1985; Kazmer et al., 1986), and the results of the present experiment with the fish meal diet, show that thrice-daily milking can increase partition of nutrients to the udder at the expense of body tissue (since, by definition, any increase in milk secretion in the absence of a change in feed intake must signify a change in nutrient partitioning). Indeed, with the fish meal diet, responses of milk production to growth hormone and to milking more frequently were additive, confirming earlier reports (Knight et al., 1992; Speicher et al., 1994). This additivity might reflect two modes of action, or it might signify an increased intensity of the same repartitioning stimulus. Because it can be argued that injection of growth hormone produces increases in plasma levels of growth hormone that are well beyond the normal physiological range (Soderholm et al., 1988; Fullerton et al., 1989) (the very exaggerated increase in plasma growth hormone in the present experiment is probably an artifact of the pattern of blood sampling), it would seem unlikely that the effects of milking frequency operate via effects on growth hormone. It would seem more likely then that the two treatments affect nutrient partitioning in the same general direction but by different mechanisms.

In conclusion, the results of the present experiment show that the amino acid nutrition of the dairy cow modulated the response to an increase in milking frequency from twice to thrice daily. Compared with growth hormone injection, increasing the frequency of milking of one half of the mammary gland had only a weak effect on the partitioning of amino acid use between body and udder.

\section{ACKNOWLEDGMENTS}

We thank I. Stewart, E. Mitchell, and J. Davidson for skilled technical assistance, and S. Robertson and his staff for care of the animals during the experiment. The bST was kindly given by Monsanto USA. The work was funded by the Scottish Executive Environment and Rural Affairs Department.

\section{REFERENCES}

ARC (Agricultural Research Council). 1980. The Nutrient Requirements of Ruminant Livestock. Commonwealth Agricultural Bureaux, Farnham Royal, Slough, Berkshire, UK.
Baracos, V., J. Brun-Bellut, and M. Marie. 1991. Tissue protein synthesis in lactating and dry goats. Br. J. Nutr. 66:451-465.

Bauman, D. E. 1992. Bovine somatotropin: Review of an emerging animal technology. J. Dairy Sci. 75:3432-3451.

Bauman, D. E., and R. G. Vernon. 1993. Effects of exogenous bovine somatotropin on lactation. Annu. Rev. Nutr. 13:437-461.

Chamberlain, D. G., J.-J. Choung, and S. Robertson. 1992. Protein nutrition of dairy cows receiving grass silage diets: Effects of feeding a protein supplement of unbalanced amino acid composition. J. Sci. Food Agric. 60:425-430.

Champredon, C., E. Debras, P. P. Mirand, and M. Arnal. 1990. Methionine flux and tissue protein synthesis in lactating and dry goats. J. Nutr. 120:1006-1015.

Choung, J.-J., and D. G. Chamberlain. 1995. The effects of intravenous supplements of amino acids on the milk production of dairy cows consuming grass silage and a supplement containing feather meal. J. Sci. Food Agric. 68:265-270.

Christensen, K., M. O. Nielsen, R. Bauer, and K. Hilden. 1989. Evaluation of mammary blood flow measurements in lactating goats using the ultrasound Doppler principle. Comp. Biochem. Physiol. 92A:385-392.

Coulon, J. B., and B. Rémond. 1991. Variations in milk output and milk protein content in response to the level of energy supply to the dairy cow: A review. Livestock Prod. Sci. 29:31-47.

DePeters, E. J., N. E. Smith, and J. Acedo-Rico. 1985. Three or two times daily milking of older cows and first lactation cows for entire lactations. J. Dairy Sci. 68:123-132.

Erdman, R. A., and M. Varner. 1995. Fixed yield responses to increased milking frequency. J. Dairy Sci. 78:1199-1203.

Flint, D. J., and M. J. Gardner. 1989. Inhibition of neonatal rat growth and circulating concentrations of insulin-like growth factor-I using an antiserum to rat growth hormone. J. Endocrinol. 122:79-86.

Fullerton, F. M., I. R. Fleet, R. B. Heap, I. C. Hart, and T. B. Mepham. 1989. Cardiovascular responses and mammary substrate uptake in Jersey cows treated with pituitary-derived growth hormone during late lactation. J. Dairy Res. 56:27-35.

Funabiki, R., Y. Watanabe, N. Nishizawa, and S. Hareyama. 1976. Quantitative aspect of the myofibrillar protein turnover in transient state on dietary protein depletion and repletion revealed by urinary excretion of NT-methylhistidine. Biochem. Biophys. Acta 451:143-150.

Itaya, K., and M. Ui. 1965. Colorimetric determination of free fatty acids in biological fluids. J. Lipid Res. 6:16-20.

Kazmer, G. W., M. A. Barnes, R. M. Akers, and R. E. Pearson. 1986. Effect of genetic selection for milk yield and increased milking frequency on plasma growth hormone and prolactin concentration in Holstein cows. J. Anim. Sci. 63:1220-1227.

Kim, C.-H., J.-J. Choung, and D. G. Chamberlain. 1999. Determination of the first-limiting amino acid for milk production in dairy cows consuming a diet of grass silage and a cereal-based supplement containing feather meal. J. Sci. Food Agric. 79:1703-1708.

Kim, C.-H., J.-J. Choung, and D. G. Chamberlain. 2000. Variability in the ranking of the three most-limiting amino acids for milk protein production in dairy cows consuming grass silage and a cereal-based supplement containing feather meal. J. Sci. Food Agric. 80:1386-1392.

Kim, C. -H., J.-J. Choung, and D. G. Chamberlain. 2001. Estimates of the efficiency of transfer of L-histidine from blood to milk when it is the first-limiting amino acid for secretion of milk protein in the dairy cow. J. Sci. Food Agric. 81:1150-1155.

Knight, C. H., J. E. Hillerton, M. A. Kerr, R. M. Teverson, A. Turvey, and C. J. Wilde. 1992. Separate and additive stimulation of bovine milk yield by the local and systemic galactopoietic stimuli of frequent milking and growth hormone. J. Dairy Res. 59:243-252.

Morrison, I. M. 1972. A semi-micro method for the determination of lignin and its use in predicting the digestibility of forage crops. J. Sci. Food Agric. 23:455-463.

Shingfield, K. J., and N. W. Offer. 1999. Simultaneous determination of purine metabolites, creatinine and pseudouridine in ru- 
minant urine by reversed-phase high-performance liquid chromatography. J. Chromatogr. B723:81-94.

Soderholm, C. G., D. E. Otterby, J. G. Linn, F. R. Ehle, J. E. Wheaton, W. P. Hansen, and R. J. Annexstad. 1988. Effects of recombinant bovine somatotropin on milk production, body composition, and physiological parameters. J. Dairy. Sci. 71:355-365.

Speicher, J. A., H. A. Tucker, R. W. Ashley, E. P. Stanisiewski, J. F. Boucher, and C. J. Sniffen. 1994. Production responses of cows to recombinantly derived bovine somatotropin and to frequency of milking. J. Dairy Sci. 77:2509-2517.
Vernon, R. G., R. A. Clegg, and D. J. Flint. 1981. Metabolism of sheep adipose-tissue during pregnancy and lactation- adaptation and regulation. Biochem. J. 200:307-314.

Wassner, S. J., J. L. Schlitzer, and J. B. Li. 1980. A rapid, sensitive method for the determination of 3-methylhistidine levels in urine and plasma using high-pressure liquid chromatography. Anal. Biochem. 104:284-289.

Wilde, C. J., D. T. Calvert, A. Daly, and M. Peaker. 1987. The effect of goat milk fractions on synthesis of milk constituents by rabbit mammary explants and on milk yield in vivo: evidence for autocrine control of milk secretion. Biochem. J. 242:285-288. 